\title{
Hydrogen Rearrangement in Molecular Ions of Alkyl Benzenes: Appearance Potentials and Substituent Effects on the Formation of $\left[\mathbf{C}_{7} \mathbf{H}_{8}\right]^{\uparrow}$ Ions $\dagger$
}

Dietmar Kuck and Hans-Fr. Grützmacher $\ddagger$

Fakultät für Chemie der Universität Bielefeld, Universitätsstr., D 4800 Bielcfeld 1, Germany

\begin{abstract}
The mechanism of the formation of $\left[\mathrm{C}_{7} \mathrm{H}_{8}\right]^{\ddagger}$ ions by hydrogen rearrangement in the molecular ions of 1-phenylpropane and 1,3-diphenylpropane has been investigated by looking at the effects of $\mathrm{CH}_{3} \mathrm{O}$ and $\mathrm{CF}_{3}$ substituents in the meta and para positions on the relative abundances of the corresponding ions and on the appearance energies. The formation of $\left[\mathrm{C}_{7} \mathrm{H}_{8}\right]^{\ddagger}$ ions from 1,3-diphenylpropane is much enhanced at the expense of the formation of $\left[\mathrm{C}_{7} \mathrm{H}_{7}\right]^{+}$ions by benzylic cleavage, due to the localized activation of the migrating hydrogen atom by the $\gamma$ phenyl group. A methoxy substituent in the 1,3-diphenylpropane, exerts a site-specific influence on the hydrogen rearrangement, which is much more distinct than in 1-phenylpropane and related 1-phenylalkanes, the rearrangement reaction being favoured by a meta methoxy group. The mass spectrum of 1-(3-methoxyphenyl)-3-(4-trideuteromethoxyphenyl)-propane shows that this effect is even stronger than the effect of para methoxy groups on the benzylic cleavage. From measurements of appearance potentials it is concluded that the substituent effect is not due to a stabilization of the $\left[\mathrm{C}_{7} \mathrm{H}_{7} \mathrm{X}\right]^{\dagger}$ product ions. Whereas the $\left[\mathrm{C}_{7} \mathrm{H}_{7}\right]^{+}$ions are formed directly from molecular ions of 1-phenylpropane and 1,3diphenylpropane, the $\left[\mathrm{C}_{7} \mathrm{H}_{8}\right]^{+}$ions arise by a two-step mechanism in which the $\sigma$ complex type ion intermediate can either return to the molecular ion or fragment to $\left[\mathrm{C}_{7} \mathrm{H}_{8}\right]^{+}$by allylic bond cleavage. Obviously the formation of this $\sigma$ complex type ion, is influenced by electron donating substituents in specific positions at the phenyl group. This is borne out by a calculation of the $\Delta H_{\mathrm{t}}$ values of the various species by thermochemical data. Thus, the relative abundances of the fragment ions are determined by an isomerization equilibrium of the molecular ions, preceding the fragmentation reaction.
\end{abstract}

\section{INTRODUCTION}

The mass spectra of higher aryl aliphatic hydrocarbons $^{1}$ are often characterized by the simultaneous appearance of two abundant fragment ions, i.e. the $\left[\mathrm{ArCH}_{2}\right]^{+}$and the $\left[\mathrm{ArCH}{ }_{2}+\mathrm{H}\right]^{t}$ ions. The former are generated-at least formally-by a simple cleavage of the benzylic $\left(\mathrm{C}^{\alpha}-\mathrm{C}^{\beta}\right)$ bond, and the latter by an additional intramolecular hydrogen transfer from the $\gamma$ position of the aliphatic chain to the aromatic nucleus as first shown by Meyerson and co-workers. ${ }^{2}$

The acceptor site for the migrating $\mathrm{H}$ atom was shown by the majority of investigations not to be the $\alpha$ but one of the ortho positions of the benzyl group. ${ }^{3}$ Thus, at least at the moment of their generation, the rearrangement products $\left(\left[\mathrm{C}_{7} \mathrm{H}_{8}\right]^{*}\right.$ in the case of unsubstituted hydrocarbons) must exhibit the structure of ionized 5-methylene-cyclohexa-1,3-diene $(b$ in Scheme 1). This is confirmed by the results of Levsen, McLafferty and Jerina ${ }^{4}$ showing that the molecular ions of 2-phenethyl alcohol directly form $b$ but not ionized toluene $(a)$ and cycloheptatriene $(c)$, the latter

$\uparrow$ Mechanisms of Mass Spectrometric Fragmentation Reactions XVIII. Part XVII: H.-Fr. Grützmacher and G. Tolkien, Tetrahedron 33, 221 (1977).

\$ Author to whom correspondence should be addressed.

(C) Heyden \& Son Ltd, 1978 two isomers being generated only by successive rearrangement from $b$.

Recently, the only objections to the $\gamma \rightarrow$ ortho migration mechanism have been raised by Williams and Bowen. ${ }^{5}$ They estimated $b$ to be $c .1 .2 \mathrm{eV}$ $\left(28 \mathrm{kcal} \mathrm{mol}^{-1}\right)$ less stable than $a$ in the electronic ground states and consequently considered $a$ to be the ionic fragmentation product. On the contrary, in line with our results (vide infra), appearance potential measurements for $\left[\mathrm{C}_{7} \mathrm{H}_{8}\right]^{+}$, generated from 2phenethyl alcohol and 1-phenylbutane, ${ }^{6 a}$ indicate that the enthalpy of formation $\Delta H_{\mathrm{f}}(b)$ of $b$ is most probably somewhat smaller than $\Delta H_{\mathrm{f}}(a)$ and considerably smaller than $\Delta H_{\mathrm{f}}(c){ }^{6 \mathrm{~b}}$

Thus, in the formation of the $\left[\mathrm{C}_{7} \mathrm{H}_{8}\right]^{+}$ion $b$ from the molecular ions of 1-phenylalkanes one has to consider the ionized aromatic ring to be the acceptor for the transferred $\mathrm{H}$ atom. We were interested in the course of such $\mathbf{H}$ migrations to aromatic systems and especially in the question of whether the $\mathrm{H}$ transfer and the cleavage of the $C^{\alpha}-C^{\beta}$ bond is a synchronous or a two-step process. Two-step fragmentation mechanisms with a $\mathbf{H}$ transfer as the first step were observed in the McLafferty 'rearrangement' of carbonyl compounds ${ }^{7}$ and in the loss of $\mathrm{OH}^{\circ}$ from the molecular ions of benzoic acid. ${ }^{8}$ In the case of the alkene elimination from the molecular ions of 1-phenylalkanes in a twostep mechanism intermediates $[Z]^{\ddagger}$ (Scheme 2 ) can be 


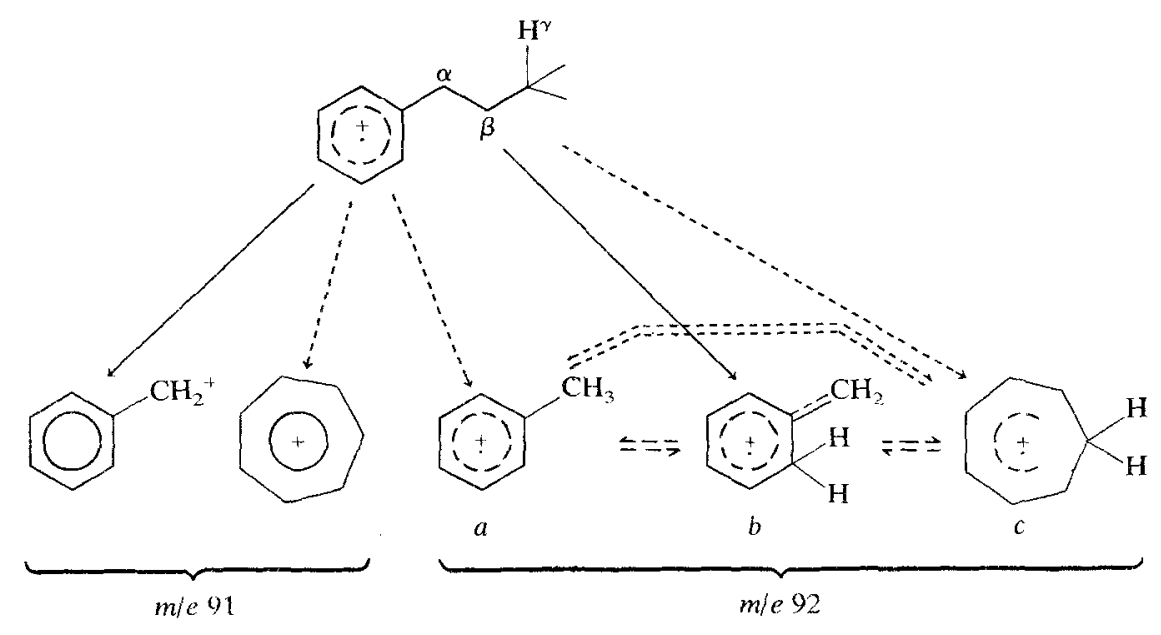

Scheme 1

anticipated corresponding closely to the $\pi$ - and $\sigma$ complexes known from electrophilic aromatic substitution.

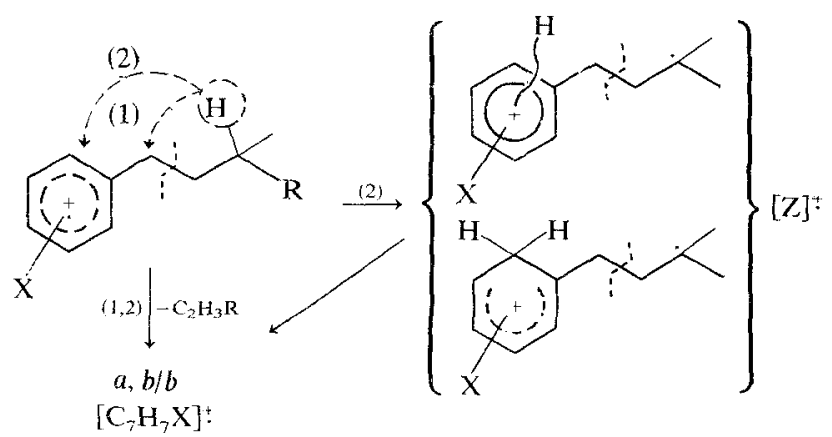

Scheme 2

A means of obtaining insight into the mechanisms of mass spectrometric fragmentations is the study of substituent effects. Although a number of publications about the effect of substituents at the aromatic nucleus ${ }^{9}$ and at the $\gamma$ - (i.e. the 3-) position of the alkyl chain $^{10}$ have appeared the possibility of a two-step mechanism of the alkene elimination from the molecular ions of 1-phenylalkanes was never discussed. ${ }^{11}$ In the present paper we report our own study of the substituent effects on the mass spectrometric fragmentation of 1-phenylpropane (1) and 1,3-diphenylpropane (2). The following paper ${ }^{12}$ will examine hydrogen exchange phenomena that accompany the formation of $\left[\mathrm{C}_{7} \mathrm{H}_{8}\right]^{ \pm}$and $\left[\mathrm{C}_{7} \mathrm{H}_{7}\right]^{+}$from $[2]^{ \pm}$.

\section{RESULTS}

1-Phenylpropane (1) is the most simple alkyl benzene whose molecular ions form $\left[\mathrm{C}_{7} \mathrm{H}_{8}\right]^{\dagger}$. In the molecular ions of 1,3-diphenylpropane (2) the additional phenyl group in the $\gamma$ position decreases the dissociation energy of the $\mathrm{C}^{\gamma}-\mathrm{H}$ bonds by approximately $20 \mathrm{kcal} \mathrm{mol}^{-1} .^{13}$ This localized bond activation ${ }^{14}$ strongly increases the formation of the rearrangement products $\left[\mathrm{C}_{7} \mathrm{H}_{8}\right]^{*}$ (Fig. 1). For both compounds 1 and
2, the methoxy and the trifluoromethyl group were chosen as examples for strong electron releasing and strong electron withdrawing substituents $X$, respectively, and placed in the para and meta positions of the aromatic ring(s). In Tables 1 and 2 the relative abundances of the ions $\left[\mathrm{C}_{6} \mathrm{H}_{7} \mathrm{X}\right]^{+}$and $\left[\mathrm{C}_{7} \mathrm{H}_{7} \mathrm{X}\right]^{+}\left({ }^{\circ} \mathrm{C}_{7}\right.$ ions') in the $70 \mathrm{eV}$ mass spectra of $\mathbf{1}, 2$ and their derivatives are given. Additionally, Fig. 1 shows the $70 \mathrm{eV}$ mass spectra of the diaryl compounds.

The mass spectrum of unsubstituted 1-phenylpropane is dominated by the $\left[\mathrm{C}_{7} \mathrm{H}_{7}\right]^{+}$ion, $\left[\mathrm{C}_{7} \mathrm{H}_{8}\right]^{+}$ being less than $2 \%$ of the total fragment ion current. Whereas a methoxy group exhibits no essential change at the para position, a $m$-methoxy substituent increases the relative abundance of the rearrangement products $\left[\mathrm{C}_{7} \mathrm{H}_{7} \mathrm{OCH}_{3}\right]^{+}(\mathrm{m} / \mathrm{e} 122)$ to $15 \%$ at the expense of $\left[\mathrm{C}_{7} \mathrm{H}_{6} \mathrm{OCH}_{3}\right]^{+}$(m/e 121). On the contrary, a trifluoromethyl group increases the relative abundances of the rearrangement products and the ratio $\left[\mathrm{C}_{7} \mathrm{H}_{7} \mathrm{X}\right]^{ \pm} /\left[\mathrm{C}_{7} \mathrm{H}_{6} \mathrm{X}\right]^{+}$only slightly and independently of its position at the ring.

The site-specific effect of the $\mathrm{OCH}_{3}$ group on the fragmentations of $[1]^{+}$is in accord with the results of Nicoletti and Lightner for the homologous 1-phenylbutanes. ${ }^{9 a, 9 b}$ As a consequence of the higher energy requirements for the dissociation of a primary $\mathrm{C}^{\gamma}-\mathbf{H}$ bond in $[\mathbf{1}]^{+}$and $[\mathbf{1 b}]^{ \pm}$(by c. $3 \mathrm{kcal} \mathrm{mol}^{-1}$ compared with a secondary one), a considerably higher $Z / Z_{0}$ ratio is observed (see footnote $b$, Table 1). On the other hand, the absence of a site-dependent effect of the trifluoromethyl group corresponds to the mass spectrometric behaviour of the likewise strongly electron withdrawing cyano and nitro substituents in 1phenylbutanes. . $^{9}, 9 \mathrm{~b}$

Introducing a methoxy substituent into one of the aromatic nuclei of 1,3-diphenylpropane, the sitespecific effect on the abundance ratios of the $C_{7}$ ions is increased drastically (Table 2). The $p$-methoxy group in $[2 \mathbf{a}]^{+}$suppresses the rearrangement reaction, dominating the mass spectrum of $\mathbf{2}$, and favours the simple benzylic cleavage. Further $[\mathbf{2 a}]^{t}$, in contrast to $[\mathbf{1 a}]^{t}$, does produce $\left[\mathrm{C}_{7} \mathrm{H}_{7} \mathrm{OCH}_{3}\right]^{t}$ ions to a small extent which might be considered as a consequence of the localized bond activation in this species. The $m$-methoxy 

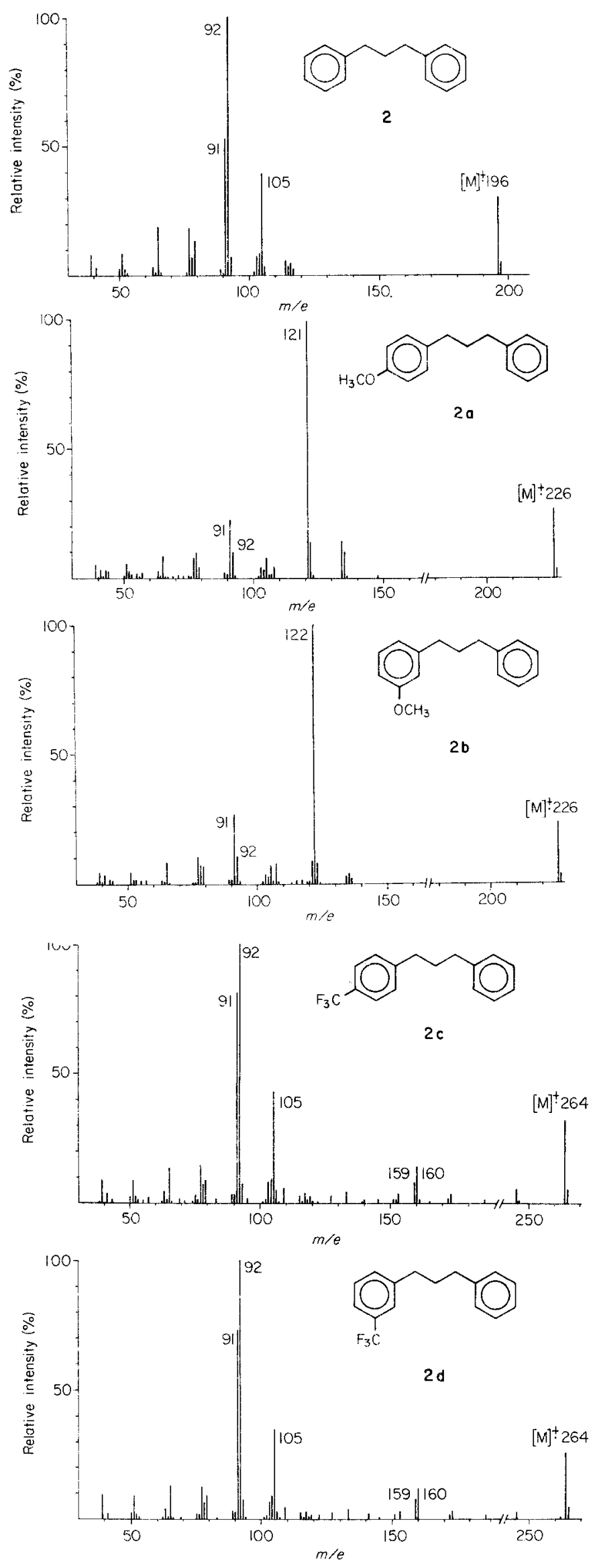

Figure 1. $70 \mathrm{eV}$ mass spectra of 1,3-diphenylpropane (2) and substituted 1,3-diphenylpropanes (2a-2d).
Table 1. Relative abundances of the $\mathrm{C}_{7}$ ions ${ }^{a}$ from 1-phenylpropanes $\mathrm{XC}_{6} \mathrm{H}_{4} \mathrm{CH}_{2} \mathrm{CH}_{2} \mathrm{CH}_{3}$ at $70 \mathrm{eV}$

\begin{tabular}{|c|c|c|c|c|c|c|}
\hline $\begin{array}{c}\text { Compound } \\
\text { No. }\end{array}$ & $x$ & $m / e$ & {$\left[\mathrm{C}_{7} \mathrm{H}_{6} \mathrm{X}\right]^{+}$} & $m / e$ & {$\left[\mathrm{C}_{7} \mathrm{H}_{7} \mathrm{X}\right]^{\frac{1}{2}}$} & $z / z_{0}^{b}$ \\
\hline 1 & $H$ & 91 & 60.7 & 92 & 1.4 & 1.00 \\
\hline $1 a$ & p- $-\mathrm{OCH}_{3}$ & 121 & 60.6 & 122 & $<0.1$ & $\ll 0.1$ \\
\hline 1b & $m-\mathrm{OCH}_{3}$ & 121 & 27.0 & 122 & 15.3 & 8.3 \\
\hline $1 \mathrm{c}$ & $p-\mathrm{CF}_{3}$ & 159 & 40.5 & 160 & 2.5 & 2.0 \\
\hline 1d & $m-\mathrm{CF}_{3}$ & 159 & 48.5 & 160 & 2.6 & 2.2 \\
\hline
\end{tabular}

a Percentage of the principal ions ${ }^{15}$ of the total fragment ion current $\sum_{39}[\mathrm{~F}]^{+}$.

$\mathrm{b}=\left[\mathrm{C}_{7} \mathrm{H}_{7} \mathrm{X}\right]^{ \pm} /[\mathrm{M}]^{+}$.

substituent in $[\mathbf{2 b}]^{+}$increases the abundance of the rearrangement products $\left[\mathrm{C}_{7} \mathrm{H}_{7} \mathrm{X}\right]^{+}$to $38 \%$ exclusively at the expense of $\left[\mathrm{C}_{7} \mathrm{H}_{6} \mathrm{X}\right]^{+}$. While $[\mathbf{2 a}]^{+}$and $[\mathbf{2 b}]^{t}$ both form the $\mathrm{C}_{7}$ ions to an almost equal amount, the portion of $\left[\mathrm{C}_{7} \mathrm{H}_{7} \mathrm{OCH}_{3}\right]^{+}$increases from under $5 \%$ to $91 \%$. A comparison of this value for $\mathbf{2 b}$ and $\mathbf{1 b}$ with the corresponding ratios in the mass spectra of long chain $m$-methoxy-1-phenylalkanes, illustrates the strong effect of the localized bond activation by the $\gamma$ phenyl group (Table 3). Evidently, the support of the rearrangement reaction by a long aliphatic chain ${ }^{1,10,17}$ is not as pronounced as by a $\gamma$ phenyl group, and only by introducing a second $m$-methoxy substituent approximately the same abundance ratio is observed.

By contrast with the results from the monophenyl compounds, a trifluoromethyl substituent reveals no site-specific effect on the competition between rearrangement reaction and simple benzylic cleavage. In contrast to $\mathbf{1 c}$ and $\mathbf{1 d}$ the abundance ratio $\left[\mathrm{C}_{7} \mathrm{H}_{7} \mathrm{CF}_{3}\right]^{ \pm} /\left[\mathrm{C}_{7} \mathrm{H}_{6} \mathrm{CF}_{3}\right]^{+}$for $2 \mathrm{e}$ and $2 \mathrm{~d}$ is considerably higher and similar to that of $\left[\mathrm{C}_{7} \mathrm{H}_{8}\right]^{ \pm} /\left[\mathrm{C}_{7} \mathrm{H}_{7}\right]^{++}$for 2 , again indicating the effect of the localized activation of the $\mathrm{C}^{\gamma}-\mathrm{H}$ bonds.

The formation of $\left[\mathrm{C}_{7} \mathrm{H}_{6} \mathrm{OCH}_{3}\right]^{+}$ions from $[\mathbf{1 a}]^{+}$and $\mathbf{2 a}]^{+}$is a very favourable fragmentation pathway due to the good stability of the $p$-methoxybenzyl ion and the high frequency factor of the benzylic cleavage. In the case of the meta isomers there is no coincidence of thermodynamically and kinetically favourable factors. In spite of its considerably smaller frequency factor the rearrangement reaction of the $\gamma$ activated $[\mathbf{2 b}]^{+}$to $\left[\mathrm{C}_{7} \mathrm{H}_{7} \mathrm{OCH}_{3}\right]^{ \pm}$largely suppresses the benzylic cleavage to the non-stabilized $m$-methoxybenzyl ion. Thus, the formation of the $\left[\mathrm{C}_{7} \mathrm{H}_{7} \mathrm{OCH}_{3}\right]^{+}$ions from $[\mathbf{2 b}]^{t}$ seems to be an energetically even more favourable process than the cleavage of $[2 \mathrm{a}]^{+}$to $\left[\mathrm{C}_{7} \mathrm{H}_{6} \mathrm{OCH}_{3}\right]^{+}$. By introducing a para and a meta methoxy group, respectively, into each of the aromatic nuclei of 1,3diphenylpropane, i.e. compound $\mathbf{3}$, the effects of both substituents on the formation of $\left[\mathrm{C}_{7} \mathrm{H}_{6} \mathrm{OCH}_{3}\right]^{+}$and $\left[\mathrm{C}_{7} \mathrm{H}_{7} \mathrm{OCH}_{3}\right]^{+}$from the same molecular ion can be studied. At the same time with 3 it can be determined whether the rearrangement reaction giving $\left[\mathrm{C}_{7} \mathrm{H}_{7} \mathrm{OCH}_{3}\right]^{ \pm}$competes effectively with the cleavage giving $\left[\mathrm{C}_{7} \mathrm{H}_{6} \mathrm{OCH}_{3}\right]^{+}$. The data show clearly that the rearrangement reaction remains dominant in the presence of a $p$-methoxy group. Moreover, it is interesting to note that the intensity ratios $\left[\mathrm{C}_{7} \mathrm{H}_{7} \mathrm{X}\right]^{ \pm} /\left[\mathrm{C}_{7} \mathrm{H}_{6} \mathrm{X}\right]^{+}$ for 3 correspond very closely to the respective ratios for unsubstituted and the monosubstituted compounds 
Table 2. Relative abundances of the $\mathrm{C}_{7}$ ions $^{\mathrm{a}}$ from 1,3-diphenylpropanes $\mathrm{XC}_{6} \mathrm{H}_{4} \mathrm{CH}_{2} \mathrm{CH}_{2} \mathrm{CH}_{2} \mathrm{C}_{6} \mathrm{H}_{5}$ at $70 \mathrm{eV}$

\begin{tabular}{llrrrrrrrr}
\hline $\begin{array}{c}\text { Compound } \\
\text { No. }\end{array}$ & \multicolumn{1}{c}{$\times$} & $m / e$ & {$\left[\mathrm{C}_{7} \mathrm{H}_{6} \times\right]^{+}$} & $m / e$ & {$\left[\mathrm{C}_{7} \mathrm{H}_{7} \mathrm{X}\right]^{+}$} & $m / e$ & {$\left[\mathrm{C}_{7} \mathrm{H}_{7}\right\}^{+}$} & $m / e$ & {$\left[\mathrm{C}_{7} \mathrm{H}_{8}\right]^{+}$} \\
$\mathbf{2}$ & $\mathrm{H}$ & 91 & $8.4^{\mathrm{b}}$ & 92 & $15.4^{\mathrm{b}}$ & 91 & $8.4^{\mathrm{b}}$ & 92 & $15.4^{\mathrm{b}}$ \\
2a & $\rho-\mathrm{OCH}_{3}$ & 121 & 36.3 & 122 & 1.8 & 91 & 8.1 & 92 & 2.6 \\
2b & $m-\mathrm{OCH}_{3}$ & 121 & 3.6 & 122 & 37.8 & 91 & 10.4 & 92 & 3.2 \\
2c & $p-\mathrm{CF}_{3}$ & 159 & 2.0 & 160 & 3.2 & 91 & 18.8 & 92 & 21.9 \\
2d & $m-\mathrm{CF}_{3}$ & 159 & 2.2 & 160 & 3.0 & 91 & 20.1 & 92 & 26.1 \\
\hline
\end{tabular}

See footnotes to Table 1.

b The abundances of $\left[\mathrm{C}_{7} \mathrm{H}_{7}\right]^{+}$and $\left[\mathrm{C}_{7} \mathrm{H}_{8}\right]^{+}$from 2 are shared equally because of its symmetry.

Table 3. Relative abundances of the $\mathrm{C}_{7}$ rearrangement ions as a portion of the total amount of $C_{\text {, }}$ ions $^{\mathbf{a}}$

\begin{tabular}{ll}
\hline \multicolumn{1}{c}{ Compound } & \multicolumn{1}{c}{$\left[\mathrm{C}_{7} \mathrm{H}_{7} \mathrm{OCH}_{3}\right]^{+/ \Sigma}\left[\mathrm{C}_{7}\right]^{+}$} \\
$3-\mathrm{H}_{3} \mathrm{CO}-\mathrm{C}_{6} \mathrm{H}_{4}-n-\mathrm{C}_{3} \mathrm{H}_{7}($ bb) & 0.36 (this work) \\
$3-\mathrm{H}_{3} \mathrm{CO}-\mathrm{C}_{6} \mathrm{H}_{4}-n-\mathrm{C}_{17} \mathrm{H}_{35}$ & 0.79 (Occolowitz $\left.{ }^{16}\right)$ \\
$3,5-\left(\mathrm{H}_{3} \mathrm{CO}\right)_{2} \mathrm{C}_{6} \mathrm{H}_{3}-n-\mathrm{C}_{15} \mathrm{H}_{31}$ & 0.88 (Occolowitz $\left.{ }^{16}\right)^{\mathrm{b}}$ \\
$3-\mathrm{H}_{3} \mathrm{CO}-\mathrm{C}_{6} \mathrm{H}_{4}-\left(\mathrm{CH}_{2}\right)_{3}-\mathrm{C}_{6} \mathrm{H}_{5}$ (2b) & 0.91 (this work) \\
\hline
\end{tabular}

a See text; values corresponding to principal ions.

b $\left[\mathrm{C}_{7} \mathrm{H}_{6}\left(\mathrm{OCH}_{3}\right)_{2}\right]^{*}$.

2, 2a and 2b, i.e. $\left[\mathrm{C}_{7} \mathrm{H}_{7} \mathrm{OCH}_{3}\right]^{ \pm} /\left[\mathrm{C}_{7} \mathrm{H}_{6} \mathrm{OCH}_{3}\right]^{+}{ }_{(\mathbf{3})} \cong$ $\left[\mathrm{C}_{7} \mathrm{H}_{7} \mathrm{OCH}_{3}\right]^{ \pm} /\left[\mathrm{C}_{7} \mathrm{H}_{6} \mathrm{OCH}_{3}\right]^{+}{ }_{(\mathbf{2 b})}$,

$$
\begin{aligned}
& {\left[\mathrm{C}_{7} \mathrm{H}_{7} \mathrm{OCD}_{3}\right]^{ \pm} /\left[\mathrm{C}_{7} \mathrm{H}_{6} \mathrm{OCD}_{3}\right]^{+}(\mathbf{3}) } \\
& \cong\left[\mathrm{C}_{7} \mathrm{H}_{7} \mathrm{OCH}_{3}\right]^{ \pm} /\left[\mathrm{C}_{7} \mathrm{H}_{6} \mathrm{OCH}_{3}\right]_{(\mathbf{2})}^{+} \text {and } \\
& {\left[\mathrm{C}_{7} \mathrm{H}_{7} \mathrm{OCH}_{3}\right]^{+} /\left[\mathrm{C}_{7} \mathrm{H}_{6} \mathrm{OCD}_{3}\right]_{(3)}^{+} \cong\left[\mathrm{C}_{7} \mathrm{H}_{8}\right]^{+} /\left[\mathrm{C}_{7} \mathrm{H}_{7}\right]_{(\mathbf{2})}^{+} }
\end{aligned}
$$

The relative abundances of the $\mathrm{C}_{7}$ ions demonstrate that the formation of $\left[\mathrm{C}_{7} \mathrm{H}_{8}\right]^{t}$ from $[2]^{ \pm}$is the most favourable fragmentation pathway, becoming even more dominant with a methoxy group meta to the aliphatic chain.

Occolowitz ${ }^{16}$ attributed the latter observation to a resonance stabilization of the $\left[\mathrm{C}_{7} \mathrm{H}_{7} \mathrm{OCH}_{3}\right]^{ \pm}$ions, but surprisingly the increase of the rearrangement rate cannot essentially be due to fragment ion stability. This is revealed by measurements of the ionization and appearance potentials $I(\mathrm{M})$ and $A[\mathrm{~F}]^{+}$(Table 5). As expected, the appearance potentials of the rearrangement ions are considerably lower than those of the ions formed by simple benzylic cleavage. The value of $A\left[\mathrm{C}_{7} \mathrm{H}_{8}\right]^{t}$ from 2 yields $\Delta H_{\mathrm{f}}\left[\mathrm{C}_{7} \mathrm{H}_{8}\right]^{*}=$ $216 \pm 3 \mathrm{kcal} \mathrm{mol}^{-1}$ in good accord with the data of Occolowitz. ${ }^{6 a}$ However, although the ionization po-

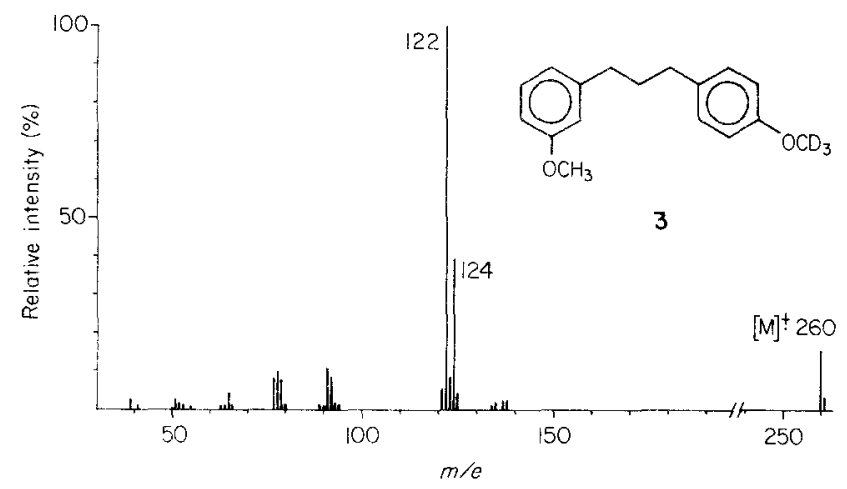

Figure 2. $70 \mathrm{eV}$ mass spectrum of 1-(3-methoxyphenyl)-3-(4trideuteromethoxyphenyl)-propane (3).
Table 4. Relative abundances of the $\mathbf{C}_{7}$

\begin{tabular}{ccc}
\multicolumn{3}{c}{ ions from 3 at 70 eV } \\
\hline$m / e$ & \multicolumn{1}{c}{ lon } & Relative abundance \\
121 & {$\left[\mathrm{C}_{7} \mathrm{H}_{6} \mathrm{OCH}_{3}\right]^{+}$} & 2.1 \\
122 & {$\left[\mathrm{C}, \mathrm{H}_{7} \mathrm{OCH}_{3}\right]^{+}$} & 38.0 \\
123 & - & .0 \\
124 & {$\left[\mathrm{C}_{7} \mathrm{H}_{6} \mathrm{OCD}_{3}\right]^{+}$} & 15.0 \\
125 & {$\left[\mathrm{C}_{7} \mathrm{H}_{7} \mathrm{OCD}_{3}\right]^{+}$} & 1.9 \\
\hline
\end{tabular}

a Percentage of the pricipal ions ${ }^{15}$ of the total fragment ion current $\sum_{39}[\mathrm{~F}]^{+}$.

tentials $I(\mathrm{M})$ decrease in the order $I(\mathbf{2})>I(\mathbf{2} \mathbf{b})>(\mathbf{3})$ the appearance potentials for the corresponding rearrangement ions $A\left[\mathrm{C}_{7} \mathrm{H}_{7} \mathrm{X}\right]^{\ddagger}$ remain constant within the limits of experimental error. This indicates clearly that the dominance of the formation of $\left[\mathrm{C}_{7} \mathrm{H}_{7} \mathrm{OCH}_{3}\right]^{+}$ from $\mathbf{2 b}$ and $\mathbf{3}$ must originate from other effects than from fragment ion stability.

\section{DISCUSSION}

The abundance ratios $\left[\mathrm{C}_{7} \mathrm{H}_{7} \mathrm{X}\right]^{+} /\left[\mathrm{C}_{7} \mathrm{H}_{6} \mathrm{X}\right]^{+}$in the $70 \mathrm{eV}$ mass spectra of the 1-phenylpropane derivatives reflect the different effects of the substituents at the $\gamma$ (3-) position of the alkyl chain and at the aromatic ring on the competition between the rearrangement reaction and the benzylic cleavage. The results clearly exclude the occurrence of a consecutive fragmentation of $\left[\mathrm{C}_{7} \mathrm{H}_{7} \mathrm{X}\right]^{ \pm}$to $\left[\mathrm{C}_{7} \mathrm{H}_{6} \mathrm{X}\right]^{+}+\mathrm{H}^{*}$. This reaction takes place at most to an extent of $10 \%$ within the ion source, which is in accord with the results of Lightner et al. on 1-phenylalkanes ${ }^{10}$ and of our results on $2 .^{12}$ In all cases the formation of the rearrangement products $\left[\mathrm{C}_{7} \mathrm{H}_{7} \mathrm{X}\right]^{+}$is increased by the presence of a phenyl group in the $\gamma$ position in the series 2-2d. As a

Table 5. Ionization $I(M)$ and appearance potentials $A[F]^{+}$ of the methoxy substituted 1,3-diphenylpropanes $\mathrm{XC}_{6} \mathrm{H}_{4} \mathrm{CH}_{2} \mathrm{CH}_{2} \mathrm{CH}_{2} \mathrm{C}_{6} \mathrm{H}_{4} \mathrm{Y}$ and their ' $\mathrm{C}_{7}$ ' fragment ions in $\mathrm{eV}^{\mathrm{a}}$

\begin{tabular}{clllllc}
\hline Compound & \multicolumn{1}{c}{$\mathrm{X}$} & \multicolumn{1}{c}{$\mathrm{Y}$} & \multicolumn{1}{c}{$l(\mathrm{M})$} & $\mathrm{A}\left[\mathrm{C}_{7} \mathrm{H}_{6} \mathrm{Y}\right]^{+}$ & $\mathrm{A}\left[\mathrm{C} \mathrm{CH}_{7} \mathrm{X}\right]^{+}$ \\
$\mathbf{2}$ & $\mathrm{H}$ & $\mathrm{H}$ & $8.60 \pm 0.1$ & $11.6^{\mathrm{b}}$ & $9.7 \pm 0.1$ \\
$\mathbf{2 a}$ & $\mathrm{H}$ & $p-\mathrm{OCH}_{3}$ & $8.18 \pm 0.05$ & $10.7 \pm 0.1$ & $\mathrm{c}$ \\
$\mathbf{2 b}$ & $m-\mathrm{OCH}_{3}$ & $\mathrm{H}$ & $8.15 \pm 0.05$ & $c$ & $9.7 \pm 0.1$ \\
$\mathbf{3}$ & $m-\mathrm{OCH}_{3}$ & $p-\mathrm{OCD}_{3}$ & $7.90 \pm 0.1$ & $11.1 \pm 0.1$ & $9.8 \pm 0.1$
\end{tabular}

a Reference: I(benzene $)=9.25 \mathrm{eV}$

b Curve tails, not parallel to ion efficiency curve of standard.

c Not reliably measurable due to the low abundance. 
consequence of the low dissociation energy of the $\mathrm{C}^{\gamma}-\mathrm{H}$ bond $\left(78 \mathrm{kcal} \mathrm{mol}^{-113 \mathrm{a}}\right)$, Szwarc et al. ${ }^{18}$ observed a very intense $\left[\mathrm{C}_{11} \mathrm{H}_{10}\right]^{t}$ ion $(m / e 142$, the benzo anologue to $\left[\mathrm{C}_{7} \mathrm{H}_{8}\right]^{+}$) formed from the molecular ions of 1,3-bis-( $\alpha$-naphthyl)-propane. As a further consequence of the localized bond activation, the participation of the $\mathrm{H}^{\beta}$ atoms in the formation of $\left[\mathrm{C}_{7} \mathrm{H}_{8}\right]^{+}$ from $[2]^{+12}$ is reduced compared with the corresponding fragmentation of the molecular ions of 1-phenylalkanes. ${ }^{10}$

The site-specific effect of the methoxy substituent is strongly enhanced in connection with the activation of the $\mathrm{C}^{\gamma}-\mathrm{H}$ bonds, the sensitivity of the ratio $\left[\mathrm{C}_{7} \mathrm{H}_{7} \mathrm{X}\right]^{+} /\left[\mathrm{C}_{7} \mathrm{H}_{6} \mathrm{X}\right]^{+}$to the position and probably to the type of the substituent being increased. Hence, it is interesting to note that contrary to the methoxy group the trifluoromethyl group does not exhibit any significant site-specific effect in the $\gamma$ 'activated' molecular ions $[\mathbf{2 c}]^{+}$and $[\mathbf{2 d}]^{ \pm}$. According to well known mechanistic concepts of the fragmentation of the molecular ions of alkylbenzenes the following situation could be assumed for the 1,3-diphenylpropanes (illustrated in part in Scheme 3). The molecular ions of the

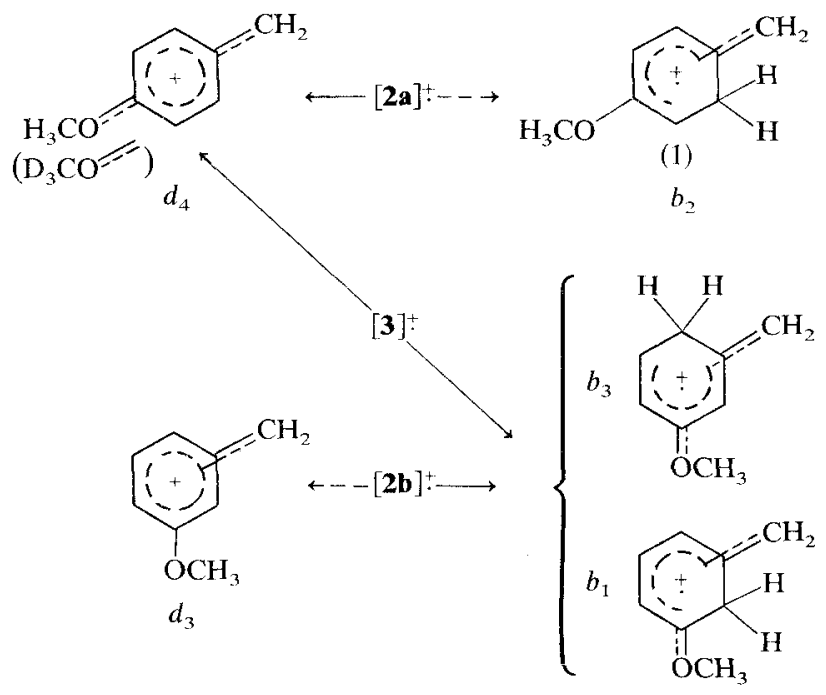

Scheme 3. Major fragmentation pathways (full arrows) of the $70 \mathrm{eV}$ 'unstable' molecular ions of the methoxy substituted 1,3diphenylpropanes.

methoxy compounds retain their structural identity ${ }^{19}$ before the formation of the $\mathrm{C}_{7}$ ions. This is shown not only by the abundance differences listed in Table 1 but also the observation that $[\mathbf{1 b}]^{\star}$ loses $\mathrm{CH}_{3} \cdot(15 \%$ of the base peak intensity), whereas $[1 \mathbf{a}]^{ \pm}$does not. A pmethoxy substituent at a phenyl ring supports the cleavage of the $\mathrm{C}^{\alpha}-\mathrm{C}^{\beta}$ bond to form resonance stabilized $\left[\mathrm{C}_{7} \mathrm{H}_{6} \mathrm{OCH}_{3}\right]^{+}$ions $d_{4}$, thus suppressing the rearrangement fragmentation to the (presumably nonstabilized) $\left[\mathrm{C}_{7} \mathrm{H}_{7} \mathrm{OCH}_{3}\right]^{ \pm}$ions $b_{2}$. A $m$-methoxy substituent, on the other hand, facilitates the formation of the presumed resonance stabilized (vide supra) 3 - and 1-methoxy-5-methylen-cyclohexa-1,3-diene radical cations, $b_{3}$ and $b_{1}$, respectively, thus suppressing the cleavage to the non-stabilized $\left[\mathrm{C}_{7} \mathrm{H}_{6} \mathrm{OCH}_{3}\right]^{+}$ion $d_{3}$. In any case the formation of ions with a toluene and cycloheptatriene structure ( $a$ and $c$ in Scheme 1) can clearly be ruled out, the $\mathrm{H}^{\gamma}$ being transferred to one of the ortho positions of the ionized anisyl moiety. The molecular ions of the $\mathrm{CF}_{3}$ substituted compounds can form the rearrangement products $\left[\mathrm{C}_{7} \mathrm{H}_{7} \mathrm{CF}_{3}\right]^{ \pm}$in the same manner by a $\gamma \rightarrow 0$ migration; indeed, in this case the present results do not exclude either the $\gamma \rightarrow \alpha$ migration or the ring expansion ${ }^{19 c}$ to $a$ and $c$, respectively (Scheme 1).

Considering the energetic data (Table 5) it is questionable as to whether the course of the fragmentation is governed by the relative stabilities of the $\left[\mathrm{C}_{7} \mathrm{H}_{6} \mathrm{X}\right]^{+}$ and the $\left[\mathrm{C}_{7} \mathrm{H}_{7} \mathrm{X}\right]^{ \pm}$ions. According to Meyer and Harrison ${ }^{19 a}$ and Tait, Shannon and Harrison ${ }^{19 b}$ the formations of $\left[\mathrm{C}_{7} \mathrm{H}_{6} \mathrm{OCH}_{3}\right]^{+}$from the molecular ions of $m-\mathrm{OCH}_{3}$ substituted ethylbenzene and benzyl chloride, respectively, require considerably higher virtual activation energies $\left(A\left[\mathrm{C}_{7} \mathrm{H}_{6} \mathrm{OCH}_{3}\right]^{+}-I(\mathrm{M})\right)$ than from the para isomers and also the formation of $\left[\mathrm{C}_{7} \mathrm{H}_{7}\right]^{+}$from ethylbenzene. ${ }^{20}$ Similar differences are observed for the benzylic cleavages of $[\mathbf{1}]^{+},[\mathbf{1 a}]^{t}$ and $[\mathbf{1 b}]^{+}$, the difference $A\left[\mathrm{C}_{7} \mathrm{H}_{6} \mathrm{OCH}_{3}\right]_{\mathbf{1 b}}{ }^{+}$ $A\left[\mathrm{C}_{7} \mathrm{H}_{6} \mathrm{OCH}_{3}\right)_{\mathbf{a k}^{+}}{ }^{+}=0.75 \pm 0.2 \mathrm{eV}$ being due at least partly to a competitive shift of the rearrangement reaction of $[\mathbf{1 b}]^{t}$ to $\left[\mathrm{C}_{7} \mathrm{H}_{7} \mathrm{OCH}_{3}\right]^{+}$.

Unfortunately, the appearance potential $A\left[\mathrm{C}_{7} \mathrm{H}_{6}\right.$ $\left.\mathrm{OCH}_{3}\right]^{+}$for the benzylic cleavage of $[\mathbf{2 b}]^{t}$ cannot be measured reliably (see Tables 2 and 5). Thus, it cannot be excluded that an increased activation energy is necessary in the case of $\mathbf{2 b}$, as well and that the drastic inversion of the ratios $\left[\mathrm{C}_{7} \mathrm{H}_{7} \mathrm{OCH}_{3}\right]^{+} /\left[\mathrm{C}_{7} \mathrm{H}_{6} \mathrm{OCH}_{3}\right]^{+}$for the 'activated' isomers $2 \mathbf{a}$ and $\mathbf{2 b}$ is a consequence of a restriction of the benzylic cleavage of $[\mathbf{2 b}]^{+}$rather than of a facilitation of a rearrangement reaction. In contrast to the mass spectra of the monophenyl compounds $\mathbf{1 a}$ and $\mathbf{1 b}$, those of the diphenyl compounds $\mathbf{2 a}$ and $\mathbf{2 b}$ are very similar in the mass region $m / e<121$ (see Fig. 1) so that from secondary fragmentations of the ' $C_{7}$ ions' there is no suggestion, using the arguments of Meyer and Harrison, ${ }^{19 a}$ of a particular increase in the energy requirements for the benzylic cleavage to $\left[\mathrm{C}_{7} \mathrm{H}_{6} \mathrm{OCH}_{3}\right]^{+}$for the meta substituted molecular ion $[\mathbf{2 b}]^{\leftarrow}$. But even if the $m$-methoxy group gives rise to a significant increase in the appearance potential $A\left[\mathrm{C}_{7} \mathrm{H}_{6} \mathrm{OCH}_{3}\right]^{+}$as compared with $A\left[\mathrm{C}_{7} \mathrm{H}_{7}\right]^{+}$for the unsubstituted $[2]^{+}$this could not explain the drastic preference of the rearrangement fragmentation of $[\mathbf{2 b}]^{+}$, because activation energy $\mathrm{A}\left[\mathrm{C}_{7} \mathrm{H}_{7} \mathrm{OCH}_{3}\right]^{+}-$ $I(\mathbf{2 b})$ has also slightly increased compared with $[2]^{+}$ (see Table 5).

The appearance potential data for $\left[\mathrm{C}_{7} \mathrm{H}_{7} \mathrm{X}\right]^{ \pm}$show that, in contrast to the $\left[\mathrm{C}_{7} \mathrm{H}_{7}\right]^{+}$ions, the rearrangement products $\left[\mathrm{C}_{7} \mathbf{H}_{8}\right]^{\dagger}$ are not stabilized appreciably by a methoxy substituent. Using perturbation molecular orbital (PMO) theory, ${ }^{21}$ the effect of a $-E$ substituent as $\mathrm{OCH}_{3}$, being isoelectronic with the $\left[\mathrm{C}_{2} \mathbf{H}_{5}\right]$ anion, on the $\pi$ electron system of 5 -methylene-cyclohexa-1,3-diene becomes understandable. This cyclic hexatriene molecule represents an even alternant hydrocarbon (AH) the $\pi$ system of which is perturbed in all positions by only a second-order effect. The stabilization thus obtained in the neutral molecule as well as in the radical cation $\left[\mathrm{C}_{7} \mathrm{H}_{7} \mathrm{OCH}_{3}\right]^{ \pm}$is considerably smaller than the stabilization of the cation of an odd 

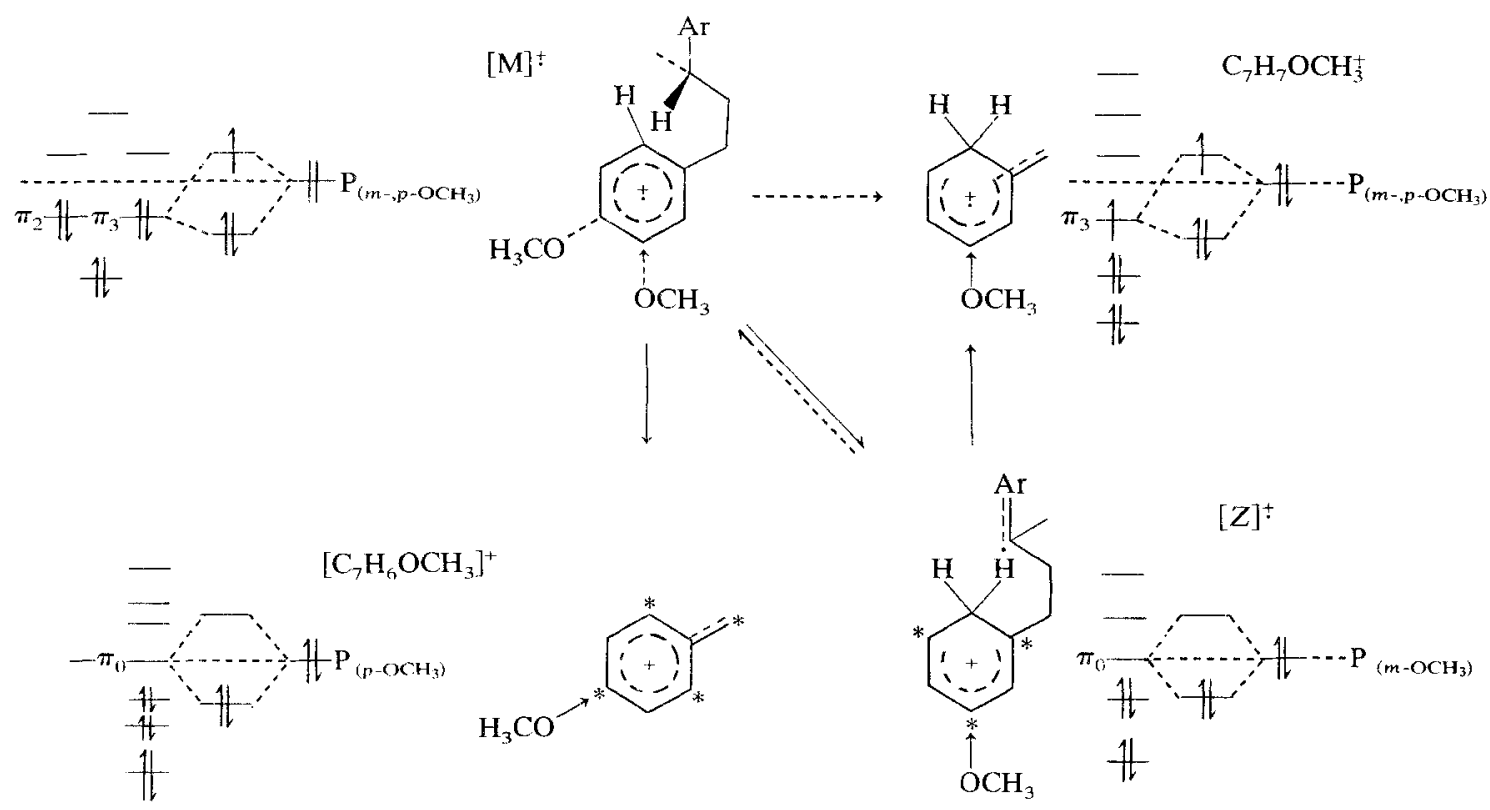

Scheme 4. Influence of $p$ - and $m-\mathrm{OCH}_{3}$ substituents on the formation of the $\mathrm{C}_{7}$ ions, as considered in terms of PMO theory. Asterisks refer to 'active' positions in the odd $\mathrm{AH}$ cations.

$\mathrm{AH}$ as the benzyl cation which is stabilized by a first-order effect of $\mathrm{OCH}_{3}$ group in an 'active' position (Scheme 4). Thus, the $\left[\mathrm{C}_{7} \mathrm{H}_{8}\right]^{t}$ ions are essentially not more stabilized by methoxy substitution than the molecular ions of the alkyl benzenes. Consequently similar reaction enthalpies can be expected for the elimination of styrene from $[\mathbf{2}]^{+},[\mathbf{2 a}]^{+},[\mathbf{2 b}]^{+}$and $[\mathbf{3}]^{!}$ to ions $\left[\mathrm{C}_{7} \mathrm{H}_{8}\right]^{+}$and $\left[\mathrm{C}_{7} \mathrm{H}_{7} \mathrm{OCH}_{3}\right]^{+}$, respectively. Hence, the assumption of particularly stabie fragmentation products cannot be a satisfactory explanation for the drastic site-specific effect of the methoxy substituent in the formation of the $\mathrm{C}_{7}$ ions. However, if a two-step mechanism $\left([\mathrm{M}]^{+} \rightarrow[\mathrm{Z}]^{ \pm} \rightarrow\left[\mathrm{C}_{7} \mathrm{H}_{7} \mathrm{X}\right]^{+}\right)$instead of a one-step mechanism (Scheme $4,[\mathrm{M}]^{+} \rightarrow$ $\left.\left[\mathrm{C}_{7} \mathrm{H}_{7} \mathrm{X}\right]^{ \pm}\right)$is supposed for the rearrangement fragmentation, the substituent effect on this reaction channel can be explained. The most stable form of $[\mathrm{Z}]^{ \pm}$is that shown in the scheme, ${ }^{12}$ the charge being localized on the protonated ring and the radical electron being 'isolated' in the other benzylic moiety of the intermediate. Hence $[\mathrm{Z}]^{+}$, being a $\sigma$ complex, represents the cation of an odd AH too, gaining considerable stabilization due to a first order perturbation by an $\mathrm{OCH}_{3}$ substituent placed in the active position para (or ortho) with respect to the protonation site. The $m$-methoxy group of $\mathbf{2 b}$ reveals a similarly strong stabilization of the intermediate $Z_{2 \mathbf{b}}$ as does the $p$ methoxy group of $\mathbf{2 a}$ in the product ions $\left[\mathrm{C}_{7} \mathrm{H}_{6} \mathrm{OCH}_{3}\right]^{+}$, whereas an intermediate $\left[\mathrm{Z}_{2 \mathrm{a}}\right]^{ \pm}$(from $\left.[\mathbf{2 a}]^{+}\right)$and the benzyl ions $\left[\mathrm{C}_{7} \mathrm{H}_{6} \mathrm{OCH}_{3}\right]^{+}$from $[\mathbf{2 b}]^{+}$ are not stabilized.

Calculating the enthalpies of formation $\Delta H_{\mathrm{f}}[\mathrm{M}]^{+}$of the molecular ions from the experimental $I(\mathrm{M})$ data and $\Delta H_{\mathrm{f}}[\mathrm{Z}]^{+}$of the corresponding intermediates (see Appendix) the enthalpies of reaction for the first (the $H$ transfer) step of the rearrangement fragmentation can be estimated. Using recent proton affinity values that have been worked out experimentally and theoretically, ${ }^{22}$ the $\mathrm{H}$ transfer is shown to be approxi- mately thermoneutral in the case of $[\mathbf{2}]^{ \pm}$and $[\mathbf{2 b}]^{ \pm}$(as well as $[3]^{\ddagger}$ ) but to be endothermic by c. $20 \mathrm{kcal} \mathrm{mol}^{-1}$ in the case of $[\mathbf{2 a}]^{\ddagger}$. Figure 3 illustrates the energy requirements of the competing isomerization and fragmentation pathways. According to Levsen and Heimbrecht, ${ }^{24}$ provided that the threshold for the isomerization step $[\mathrm{M}]^{+} \rightarrow[\mathrm{Z}]^{+}$is considerably lower than that for the fragmentation step $[\mathrm{Z}]^{+} \rightarrow\left[\mathrm{C}_{7} \mathrm{H}_{7} \mathrm{X}\right]^{+}$ (which seems to be reasonable since activation energies for the abstraction of benzylic $\mathbf{H}$ atoms from neutral molecules by hydrocarbon radicals generally require not more than $c .10 \mathrm{kcal} \mathrm{mol}^{-125}$ ) the results suggest an equilibrium of the molecular ions $[2]^{+}$and $[\mathrm{Z}]^{\ddagger}$. Whereas in the case of $\mathbf{2 a}$ the (primary) molecular ions $[\mathbf{2 a}]^{t}$ will predominate, mainly forming $\left[\mathrm{C}_{7} \mathrm{H}_{6} \mathrm{OCH}_{3}\right]^{+}$ions by benzylic cleavage (see Scheme 4) the equilibrium mixture of the isomerization $[2]^{+} \rightleftharpoons$ $\left[\mathrm{Z}_{2}\right]^{\dagger}$ will contain considerable amounts of the $\sigma$ complex isomer, while the equilibrium mixture $[\mathbf{2 b}]^{+} \rightleftharpoons$ $\left[\mathrm{Z}_{\mathbf{2 b}}\right]^{+}$will consist predominantly of the $\sigma$ complex because of the slightly exothermic formation of $\left[\mathrm{Z}_{\mathbf{2 n}}\right]^{t}$

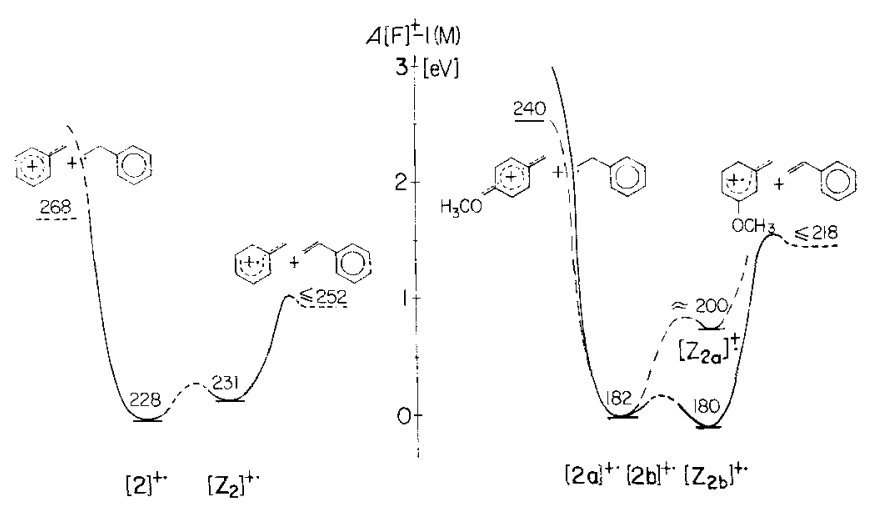

Figure 3. Enthalpy diagram for isomerization and fragmentation of the molecular ions of 2 (left) and of $\mathbf{2 a}$ (dashed lines - $-)$ and $2 \mathrm{~b}$ (full lines - ) , in $\mathrm{kcal} \mathrm{mol}^{-1}$. 
(Fig. 3). The formation of the 'rearrangement' ions $\left[\mathrm{C}_{7} \mathrm{H}_{8}\right]^{ \pm}$and $\left[\mathrm{C}_{7} \mathrm{H}_{7} \mathrm{OCH}_{3}\right]^{+}$, respectively, from these intermediates in the second step is a simple cleavage of the now allylic $\mathrm{C}^{\alpha}-\mathrm{C}^{\beta}$ bond. This reaction is characterized by a high frequency factor but, in accordance with experiment and PMO theory, by a high endothermicity as well. Thus, in the case of $\mathbf{2 b}$, the high abundance of $\left[\mathrm{C}_{7} \mathrm{H}_{7} \mathrm{OCH}_{3}\right]^{ \pm}$indicates that the loss of the stabilizing effect of the 'meta' methoxy substituent during the tragmentation of $\left[\mathrm{Z}_{\mathbf{2 b}}\right]^{\dagger}$ is more than compensated by the particularly efficient isomerization of $[\mathbf{2 b}]^{t}$ to this intermediate. Contrary to the methoxy group the trifluoromethyl group, being $\mathrm{a}+\mathrm{M}$ substituent, ${ }^{21}$ destabilizes not only the molecular ions $[\mathbf{2 c}]^{+}$and $[\mathbf{2 d}]^{+}$but also the corresponding $\sigma-$ complexes $\left[\mathrm{Z}_{\mathbf{2 c}}\right]^{+}$and $\left[\mathrm{Z}_{\mathbf{2 d}}\right]^{\dagger}$ both in the para and meta positions to very similar amounts. ${ }^{22 \mathrm{e}}$ Using our ionization potential and recent proton affinity data, ${ }^{22}$ the energy requirements for the hypothetical formation of $\left[\mathrm{Z}_{\mathbf{2 c}}\right]^{+}$and $\left[\mathrm{Z}_{\mathbf{2 d}}\right]^{+}$from $[\mathbf{2 c}]^{+}$and $[\mathbf{2 d}]^{+}$, respectively, can be estimated to be very similar to that of the formation of $\left[\mathrm{C}_{7} \mathrm{H}_{8}\right]^{\ddagger}$ from $[2]^{\ddagger}$ via $\left[\mathrm{Z}_{2}\right]^{\ddagger}$ in both cases.

This is in accordance with the observed ratios of abundances of $\left[\mathrm{C}_{7} \mathrm{H}_{7} \mathrm{CF}_{3}\right]^{t}$ and $\left[\mathrm{C}_{7} \mathrm{H}_{6} \mathrm{CF}_{3}\right]^{+}$being similar to those of $\left[\mathrm{C}_{7} \mathrm{H}_{8}\right]^{+}$and $\left[\mathrm{C}_{7} \mathrm{H}_{7}\right]^{+}$from $[2]^{t}$. The low abundances of these ions indicate that charge and radical are localized mainly in the unsubstituted moiety of the molecular ions.

\section{CONCLUSION}

The experimental results show conclusively that the main fragmentation of the molecular ions of 1,3diphenylpropane (2) forming $\left[\mathrm{C}_{7} \mathrm{H}_{8}\right]^{t}$ ions and neutral styrene occurs in two steps, i.e. $\mathrm{H}^{\gamma}$ transfer and cleavage of the $\mathrm{C}^{\alpha}-\mathrm{C}^{\beta}$ bonds. The highly site-specific substituent effect of the $\mathrm{OCH}_{3}$ group on this reaction and on other alkylbenzene systems suggests that this two-step mechanism is characteristic for fragmentations involving $\mathrm{H}$ migrations.

The reactivity of the molecular ions of higher 1phenylalkanes exhibit some interesting features. After ionization, induced by electron impact, a mixture of isomeric molecular ions, $[\mathrm{M}]^{\star}$ and $[\mathrm{Z}]^{+}$, is generated by $\gamma \rightarrow o$ transfer of a hydrogen from a (in the case of $[2]^{\ddagger}$, favourably activated) $\mathrm{C}^{\gamma}-\mathrm{H}$ bond, each isomer decomposing to characteristic products by simple $\mathrm{C}^{\alpha}-$ $\mathrm{C}^{\beta}$ bond cleavage. Thus, benzyl ions $\left[\mathrm{C}_{7} \mathrm{H}_{7}\right]^{+}$are generated from $[\mathrm{M}]^{ \pm}$and 5-methylene-cyclohexa-1,3diene radical ions $\left[\mathrm{C}_{7} \mathrm{H}_{8}\right]^{ \pm}$from $[\mathrm{Z}]^{+}$. The composition of the equilibrium mixture is influenced by substituents at the aromatic ring and at the $\gamma$ position. However, a substituent does not govern the abundance ratio of the ' $C_{7}$ ions' by its influence on the cleavage of the $\mathrm{C}-\mathrm{C}$ bond, but decisively by its influence upon the position of the equilibrium $[\mathrm{M}]^{\ddagger} \rightleftharpoons$ $[Z]^{ \pm}$. This implies that the activation energy for the isomerization is considerably smaller than that for both fragmentation steps.

As will be shown in the following paper, the interconversion of $[\mathrm{M}]^{+}$and $[\mathrm{Z}]^{+}$and thus the main as- sumption of the two-step fragmentation proposed in this paper, can be proved by means of deuterium. labelled analogues of 1,3-diphenylpropane.

\section{EXPERIMENTAL}

\section{Mass spectrometric measurements}

The mass spectra were obtained with a Varian MAT CH-7 single focusing mass spectrometer; ionization and appearance energies were measured with the same instrument and, semi-automatically, with a Vacuum Generators MM 12B single focusing instrument using the semi-log plot method. ${ }^{26}$ The instrument conditions were: $(\mathrm{CH}-7)$ high temperature inlet $150^{\circ} \mathrm{C}$ for compounds 1-1d and $200^{\circ} \mathrm{C}$ for $\mathbf{2 - 2 d} ; \mathbf{3}$ was introduced via the direct inlet system, source pressure $\leqslant 3 \times 10^{-6}$ Torr, source temperature $215 \pm 10^{\circ} \mathrm{C}$, emission current 300 and $30 \mu \mathrm{A}$, respectively; (MM 12B) high temperature inlet $150^{\circ} \mathrm{C}, 3$ was introduced on silica gel via the direct inlet system, source pressure $\leqslant 3 \times 10^{-6}$ Torr, source temperature $200 \pm 10^{\circ} \mathrm{C}$, emission current $20 \mu \mathrm{A}$.

\section{Preparation of the compounds}

1 was a commercial sample. 1a was prepared by methylation of 4- $n$-propylphenol with $\mathrm{CH}_{2} \mathrm{~N}_{2}$ followed by purification over $\mathrm{Na}$. 1b was obtained in the conventional manner from 3-methoxybenzaldehyde and ethylmagnesium bromide, oxidation of the carbinol with $\mathrm{MnO}_{2}$ followed by Wolff-Kishner-Huang-Minlon reduction. 1c and $\mathbf{1 d}$ were prepared similarily from 3and 4-bromobenzotrifluoride, respectively and propionaldehyde ( $p$ - and $m$-carbinols: b.p. 13 107$108^{\circ} \mathrm{C}$ and b.p. ${ }_{11} 102-103^{\circ} \mathrm{C}$, resp., yields $80-90 \%$, the phenones were not isolated, 1c: b.p. $1766^{\circ} \mathrm{C}$, yield $52 \%$ based on the carbinol, 1d: b.p. $760172-173^{\circ} \mathrm{C}$, $76 \%)$.

$\mathbf{2}, \mathbf{2 a}$ and $\mathbf{2 b}$ were synthesized by condensation of the appropriate aldehydes with acetophenone, catalytic hydrogenation of the chalcones to the saturated phenones followed by Clemmensen or Wolff-KishnerHuang-Minlon reduction, respectively. In the case of $\mathbf{2 a}$ and $\mathbf{2 b}$ the latter method generated considerable amounts of the corresponding phenols which were re-methylated with $\mathrm{CH}_{2} \mathrm{~N}_{2}$, the products being purified over Na (2b: b.p. $0.2114-115^{\circ} \mathrm{C}, \mathrm{n}_{\mathrm{D}}^{22} 1.5591$, yield based on the phenone $42 \%$ ). $2 \mathrm{c}$ and $2 \mathrm{~d}$ were obtained in the same manner as $\mathbf{1 c}$ and 1d using hydrocinnamaldehyde ( $p$ - and $m$-carbinols: b.p.0.2 134$136^{\circ} \mathrm{C}, \mathrm{n}_{\mathrm{D}}^{18.5} 1.5229,73 \%$, and b.p. $0.127-128^{\circ} \mathrm{C}$, $\mathrm{n}_{\mathrm{D}}{ }^{17.5} 1.5213,80 \%$, resp.; $p$ - and $m$-phenones: m.p. $47-47.5^{\circ} \mathrm{C}$ from EtOH, $92 \%$, and m.p. $31-32{ }^{\circ} \mathrm{C}$, EtOH, 93\%, resp.; 2c: b.p. $.35113-114^{\circ} \mathrm{C}, 48 \%$, and 2d: b.p.0.15 $\left.93-94^{\circ} \mathrm{C}, \mathrm{n}_{\mathrm{D}}{ }^{19.5} 1.5093,68 \%\right) .3^{27}$ was obtained from 4-hydroxyacetophenone and 3methoxybenzaldehyde via the chalcone, catalytic hydrogenation to the saturated phenone (m.p. 113$114^{\circ} \mathrm{C} / \mathrm{EtOH}, 83 \%$ ), Clemmensen reduction forming 
the corresponding propane (b.p. $\cdot_{0.3} 187-192^{\circ} \mathrm{C}, 71 \%$ ) and etherification with $\mathrm{CD}_{3} \mathrm{I}\left(3\right.$ : b.p. $._{0.15} 147-148^{\circ} \mathrm{C}$, $53 \%$ ). Elemental analyses of new compounds fitted satisfactorily with the calculated compositions.

\section{Acknowledgement}

The investigations were supported by the 'Forschungsprojekt 2142 der Universität Bielefeld.

\section{REFERENCES}

1. H. M. Grubb and S. Meyerson, in Mass spectrometry of Organic lons,' ed. by F. W. McLafferty, Chapt. 10. Academic Press, New York (1963).

2. J. D. McCollum and S. Meyerson, J. Am. Chem. Soc. 81, 4116 (1959).

3. For a recent summary, see: J. T. Bursey, M. M. Bursey and D. G. I. Kingston, Chem. Rev. 73, 191 (1973); (b) I. Howe in Mass Spectrometry, Vol. 2, Specialist Periodical Reports, Senior reporter D. H. Williams, p. 82. The Chemical Society, London (1973).

4. K. Levsen, F. W. McLafferty and D. M. Jerina, J. Am. Chem. Soc. 95, $6332(1973)$

5. D. H. Williams and R. D. Bowen, Org. Mass Spectrom. 11, 223 (1976).

6. (a) J. Occolowitz, cited in Ref. 4 as a private communication; (b) On finishing this paper, a MINDO/3 study of $\left[\mathrm{C}_{7} \mathrm{H}_{8}\right]^{+}$isomers appeared yielding $\Delta H_{f}(b)=219$ $\Delta H_{f}(a)=212$ and $\Delta H_{f}(c)=207 \mathrm{kcal} \mathrm{mol}^{-1}:$ M. J. S. Dewar and D. Landman, J. Am. Chem. Soc. 99, 2446 (1977).

7. For a recent summary, see: D. G. I. Kingston, J. T. Bursey and M. M. Bursey, Chem. Rev. 74, 215 (1974)

8. (a) J. H. Beynon, B. E. Job and A. E. Williams, Z. Natur forsch. Teil A 20, 885 (1965); (b) S. Meyerson and J. L Corbin, J. Am. Chem. Soc. 87, 3045 (1965); (c) L. Howe and F. W. McLafferty, J. Am. Chem. Soc. 92, 3797 (1970); (d) for further references see: I. Howe, Ref. $3 b$, and J. H. Bowie Ref. 3b, Chapt. 3.

9. R. Nicoletti and D. A. Lightner, (a) J. Am. Chem. Soc. 90, 2997 (1968); (b) Tetrahedron Lett. 4553 (1968); (c) H. Nakata and A. Tatematsu, Tetrahedron Lett. 4303 (1969)

10. D. A. Lightner, G. B. Quistad and E. Irwin, Appl. Spectrosc. 25, 253 (1971)

11. See also: (a) A. M. Duffield, R. Beugelmans, H. Budzikiewicz, D. A. Lightner, D. H. Williams and C. Djerassi, J. Am. Chem. Soc. 87, 805 (1965); (b) A. F. Gerrard and C. Dierassi, J. Am. Chem. Soc. 91, 6808 (1969); (c) N. M. M. Nibbering and Th. J. deBoer, Tetrahedron 24, 1415 (1968) (d) N. M. M. Nibbering and Th. J. deBoer, Tetrahedron 24 1427 (1968): (e) A. Venema, N. M. M. Nibbering and Th. J. deBoer, Org. Mass Spectrom. 3, 583 (1970); (f) H. Schwarz, C. Köppel and. F. Bohlmann, Org. Mass Spectrom. 7, 881 (1973): (g) A. Venema and N. M. M. Nibbering, Org. Mass Spectrom. 9, 628 (1974); (h) C. Köppel and H. Schwarz, Org. Mass Spectrom. 11, 101 (1976).

12. D. Kuck and H. F. Grützmacher, Org. Mass. Spectrom. 13, 90 (1978).

13. (a) J. A. Kerr, Chem. Rev. 66, 465 (1966); (b) T. L. Cottrell, The Strength of Chemical Bonds, 2nd Edn, Chapt. 9. Butterworths, London (1963).

14. S. Meyerson and L. C. Leitch, J. Am. Chem. Soc. 93, 2244 (1971).
15. IUPAC Recommendations on Symbolism and Nomenclature for Mass Spectroscopy, Org. Mass Spectrom. 12, 115 (1977).

16. J. L. Occolowitz, Anal. Chem. 36, 2177 (1964)

17. D. Kuck and H. F. Grützmacher, in preparation.

18. P. Caluwe, K. Shimada and M. Szwarc, J. Am. Chem. Soc 95, 1433 (1973)

19. For studies on positional retention and/or randomization of substituents, see e.g. Ref. 3a and especially: (a) F. Meyer and A. G. Harrison, Can. J. Chem. 42, 2008 (1964); (b) J. M. S. Tait, T. W. Shannon and A. G. Harrison, J. Am. Chem. Soc. 84, 4 (1962).

20. Using data from: J. L. Franklin, J. G. Dillard, H. M. Rosenstock, J. T. Herron, K. Draxl and F. H. Field, Ionization Potentials, Appearance Potentials and Heats of Formation of Gaseous Positive lons, U.S. Department of Commerce, NSRDS-NBS 26, Washington (1969).

21. M. J. S. Dewar and R. C. Dougherty, The PMO Theory of Organic Chemistry, Plenum Press, New York (1975).

22. (a) Y. K. Lau and P. Kebarle, J. Am. Chem. Soc. 98,7452 (1976): (b) R. Yamdagni and P. Kebarle J. Am. Chem Soc. 98, 1320 (1976); (c) S.-L. Chong and J. L. Franklin, J. Am Chem. Soc. 94, 6630 (1972) and references cited therein; (d) J. L. Devlin III, J. F. Wolf, R. W. Taft and W. J. Hehre, J. Am Chem. Soc. 98, 1992 (1976); (e) J. M. McKelvey, S. Alexandratos, A. Streitwieser Jr, J.-L. M. Abboud and W. J. Hehre, J. Am. Chem. Soc. 98, 244 (1976); (f) W. J. Hehre, R. T. Mclver Jr, J. A. Pople and P. v. R. Schleyer, J. Am. Chem. Soc. 96, 7162 (1974); (g) R. S. Greenberg, M. M. Bursey and L. G. Pedersen, J. Am. Chem. Soc. 98, 4061 (1976).

23. (a) G. A. Olah, R. H. Schlosberg, R. D. Porter, Y. K. Mo, D. P. Kelly and G. D. Mateescu, J. Am. Chem. Soc. 94, 2034, (1972); (b) B. S. Freiser, R. L. Woodin and J. L. Beauchamp, J. Am. Chem. Soc. 97, 6893 (1975).

24. K. Levsen and J. Heimbrecht, Org. Mass Spectrom: 12, 131 (1977).

25. K. U. Ingold, in Free Radicals, Vol. 1, ed. by J. K. Kochi, Wiley, New York (1973) and references cited therein.

26. R. W. Kiser, Introduction to Mass Spectrometry and Its Applications, Chapt. 8. Prentice-Hall, Englewood Cliffs (1965).

27. 3 has been prepared very recently by M. A. Schwarz, B. F. Rose, R. A. Holton, S. W. Scott and B. Vishnuvajjala, J. Am. Chem. Soc. 99, 2571 (1977).

Received 25 July 1977; accepted 19 August 1977

(C) Heyden \& Son Ltd, 1978

\section{APPENDIX}

Thermochemical increment ${ }^{20}$ calculations yield $\Delta H_{\mathrm{f}}(\mathbf{2})=29 \mathrm{kcal} \mathrm{mol}^{-1} \quad$ and $\quad \Delta H_{\mathrm{f}}(\mathbf{2} \mathbf{a})=\Delta H_{\mathrm{f}}(\mathbf{2} \mathbf{b})=$ $-6 \mathrm{kcal} \mathrm{mol}^{-1}$. The $\Delta H_{\mathrm{f}}[\mathrm{Z}]^{+}$values are calculated according to

$$
\Delta H_{\mathrm{f}}[\mathrm{Z}]^{+}=\Delta H_{\mathrm{f}}(\mathrm{M})+\mathrm{D}\left(\mathrm{C}^{\gamma}-\mathrm{H}\right)+\mathrm{I}\left(\mathrm{H}^{*}\right)-\mathrm{PA}(\mathrm{Ar})
$$

combining the dissociation energy $\mathrm{D}\left(\mathrm{C}^{\gamma}-\mathrm{H}\right)=$ $78 \mathrm{kcal} \mathrm{mol}^{-1},{ }^{13 \mathrm{a}, 13 \mathrm{~b}} \mathrm{I}\left(\mathrm{H}^{*}\right)=314 \mathrm{kcal} \mathrm{mol}^{-122 \mathrm{a}}$ and the value of the proton affinity of benzene, given by
$\mathrm{Kebarle}^{22 \mathrm{a}, 22 \mathrm{~b}} \quad \mathrm{PA}(\mathrm{benzene})=183.7 \mathrm{kcal} \mathrm{mol}^{-1} \quad$ (see also Ref. 22c). PA(toluene) exceeds this value by at least c. $6 \mathrm{kcal} \mathrm{mol}^{-1} .^{22 \mathrm{a}-22 \mathrm{e}} \mathrm{A}$ ( $\gamma$-phenyl)-propyl group (at the 'para' position of the benzene nucleus in the place of methyl) increases PA(toluene) by additional c. $2 \mathrm{kcal} \mathrm{mol} \mathrm{l}^{-122 \mathrm{e} 22 \mathrm{f}}$ but this should be fully compensated by the $2 \mathrm{kcal} \mathrm{mol}^{-122 \mathrm{~d}}$ due to ortho instead of para protonation which occurs predominantly in the bimolecular case. ${ }^{23}$ PA(anisole) exceeds PA(benzene)

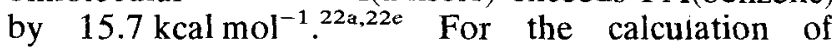


$\Delta H_{\mathrm{f}}\left[\mathrm{Z}_{\mathbf{2 b}}\right]^{+}$and $\Delta H_{\mathrm{f}}\left[\mathrm{Z}_{\mathbf{2 a}}\right]^{+}$additivity of substituent effects is assumed in accordance with the results of Hehre et l. $^{22 \mathrm{~d}}$ A very recent STO-3G study of Bursey et $a l^{22 g}$ yields $\mathrm{PA}(m$-methylanisole $)=220 \mathrm{kcal} \mathrm{mol}^{-1}$ which is certainly too high; however, it is interesting to note that $\Delta H_{\mathrm{f}}(e)$ is equal to $\Delta H_{\mathrm{f}}(f),{ }^{22 \mathrm{~g}}$ whereas $\Delta H_{\mathrm{f}}(\mathrm{g})$, concerning the para isomer, is higher by some $20 \mathrm{kcal} \mathrm{mol}^{-122 \mathrm{~g}}$ (see also Scheme 4). This considera- ble difference is supported by the corresponding PA increment of $p$ - and $m$-hydroxy substituents. ${ }^{220}$

$e$<smiles>COc1ccc(C)c(C)c1</smiles><smiles>COc1cccc(C)c1C</smiles><smiles>COc1ccc(C)c(C)c1</smiles> 